\title{
Foreword
}

\section{Stewart Macaulay}

Miles Davis' Kind of Blue is one of the great jazz recordings. The first selection on the album is called 'So What'. It poses the basic question dealt with in a Research Handbook on Remedies in Private Law. It is a major triumph to establish that a defendant's negligent conduct was the proximate cause of the plaintiff's injury. It is not easy to show that there was a binding contract that the defendant's attempted performance materially breached. Yet as Davis' title reminds us, once the. plaintiff has done all this work, So What? What can or will the legal system do to respond to the plaintiff's injury? This first sends us to the remedial rules. There is a great deal to learn here. These remedial rules can significantly affect the actual consequences of the substantive law. If we neglect them, we may assume a state of the law that doesn't exist. However, if we really want to know So What, we have to look at all that is involved beyond the rules before the injured plaintiff receives any response as a result of her or his bringing a law suit.

It is too easy to forget that law is not free. An injured plaintiff has to decide to bring a law suit. She must consider what this will cost as compared to the amount of the judgment she might gain. Some of the costs are directly financial. Lawyers and expert witnesses cost money. Other costs involve such things as injury to reputation or the risk of losing a beneficial long-term relationship. Those who bring lawsuits are not always applauded by friends, family, business associates and others who count. In at least some long-term continuing relationships, there may be a norm that buyers and sellers should help the other party who faces major problems in performing a contract. We can ask whether a family member or a neighbour should sue if a loss is not covered by insurance.

Making the choice even harder, in all but a few situations, a potential plaintiff must make a judgment about the likelihood that she will win and how much. Many of the rules in both torts and contracts call for qualitative normative judgments. While application of these rules may produce fairly certain results in extreme situations, often attempts to predict how they will be applied to facts that are less than certain only will yield imprecise judgments or wild guesses. Ideally, the plaintiff will be helped by a lawyer devoted to her interests. Those who have studied lawyer-client relationships remind us that at least some times, the lawyer's and the client's interests are not entirely the same.

There is a growing literature in the United States that often is labelled The Vanishing Trial. Despite a growing population, the number of trials has declined. It is not entirely clear why this is so. To some extent, the world may be a nicer place and we may have fewer injuries that could spawn litigation. On the other hand, the costs of litigation and the difficulties in predicting what courts will do, might provoke more settlements. Some American judges are proud of their ability to persuade parties to settle and avoid time-consuming and costly trials. Of course, settlements may be one sided and reflect differences in wealth or they may arrive at the best possible result in a bad situation. In other instances, people may have discovered that they cannot afford the investment demanded to assert rights when the outcome is so uncertain. They find that they cannot assert what they believe are their rights. Some will discover that the defendant is unlikely to be able to pay a judgment. One reason why people default on performing contracts, after all, is that they ran into financial trouble. A person who commits a tort may have no accident insurance because he cannot afford it. All filing a law suit may accomplish is to provoke bankruptcy or a similar proceeding. Some situations that might 
once have prompted individual litigation are now institutionalised. Insurance adjusters, for example, confront an organised plaintiffs' bar. What we know suggests that this works well in ordinary cases where the losses are not huge. When the damages soar, the results of organised bureaucracies often lead to criticism.

Finally, Galanter has pointed out the advantages held by repeat players. Large organisations draft standard form contracts designed to ward off litigation and to gain advantages if any takes place. A seller's document, for example, will disclaim consequential damages; a buyer's document will give it the right to cancel the deal 'for convenience'. Some cases that formerly would have gone to court might have been removed to arbitration. At the minimum, this usually helps control any negative publicity that litigation before the public courts might create.

The editors of this handbook, and the authors of the chapters included, are aware of all this and deal with such matters in their own writing. They know all too well that if we want to respond to Miles Davis' question So What, we need some sense of the law in action. The questions dealt with in this book are not easy to answer, but this doesn't undercut their vital importance. I welcome this handbook. 